Economics Development Analysis Journal 5(2)(2016)

\title{
Implementasi Community Development Bidang Pendidikan dalam Meningkatkan Kualitas SDM dan Mengatasi Kemiskinan
}

Eddy Cahyadi $^{1 \bowtie}$, Reta Yudistyana $^{2}$

PT Badak NGL, Indonesia

\section{Info Artikel}

Sejarah Artikel:

Diterima Januari 2016

Disetujui Maret 2016

Dipublikasikan Mei 2016

\section{Keywords:}

community development,

education, poverty

\begin{abstract}
Abstrak
Penelitian ini memiliki beberapa tujuan yaitu mengidentifikasi model implementasi program Community Development bidang pendidikan yang dilakukan PT Badak NGL dan mengidentifikasi dampak implementasi program Community Development bidang pendidikan tersebut. Jenis penelitian ini adalah penelitian kualitatif dengan metode analisis deskriptif. Sumber data yang digunakan adalah primer dan sekunder. Hasil penelitian menunjukkan bahwa program Community Development bidang pendidikan yang dilakukan oleh PT Badak NGL adalah pemberian beasiswa penuh untuk siswa SMP, SMA, dan Perguruan Tinggi serta beasiswa untuk mahasiswa LNG Academy; peduli pendidikan di daerah terisolir dengan membuat boarding community untuk siswa dari daerah terisolir agar dapat mengikuti Ujian Akhir Nasional; dan program peningkatan kualitas guru dengan memberikan pelatihan kepada guru. Program-program tersebut dilaksanakan oleh PT Badak NGL sebagai bentuk tanggung jawab dan peran serta PT Badak NGL mewujudkan masyarakat yang berdaya, mengurangi tingkat kemiskinan, dan turut dalam proses pembangunan yang berkelanjutan.
\end{abstract}

\begin{abstract}
This research aims to determine the implementation of Community Development education model conducted by PT Badak NGL, and to identified Community Development program implementation effect in education sector. The research type is qualitative research with descriptive analysis methods with data sources of primary and secondary data. The research results indicate that Community Development education program given by PT Badak NGL is a full scholarship awarding scholarships for junior high school students, high schools and universities as well as scholarships for students of the Academy of LNG; care about education in remote areas by creating a community for boarding students from remote areas in order to follow the National Exam; and programs to improve the quality of teachers by providing training to teachers. The programs were implemented by PT Badak NGL as a form of responsibility of PT Badak NGL in the role of PT Badak NGL realize empowered community, reduce poverty and contribute in the process of sustainable development.
\end{abstract}

(C) 2016 Universitas Negeri Semarang

Alamat korespondensi:
Satimpo, Bontang Sel., Kota Bontang, Kalimantan Timur
E-mail: ecahyadi@badaklng.co.id

ISSN 2252-6765 


\section{PENDAHULUAN}

Kemiskinan merupakan masalah yang terjadi di banyak daerah. Untuk mengatasi masalah tersebut, pemerintah melakukan berbagai upaya untuk mengatasinya tetapi lebih banyak upaya pengentasan kemiskinan harus dilakukan untuk provinsi termiskin dan daerah pedesaan (Qi \& Wu, 2015). Tujuannya adalah peningkatan kesejahteraan dan ekonomi masyarakat.

Menurut Kuncoro (2006:120), penyebab kemiskinan akan bermuara pada teori lingkaran setan kemiskinan (vicious cycle of poverty) di mana menurut teori tersebut penyebab kemiskinan yang tidak tahu asal muasalnya dan akan terus berputar, tidak berujung pangkal dan untuk menanggulanginya perlu diputus rantai penyebab kemiskinan tersebut. Adanya keterbelakangan, ketidaksempurnaan pasar, dan kurangnya modal menyebabkan rendahnya produktifitas. Rendahnya produktifitas selanjutnya dapat menyebabkan rendahnya pendapatan yang mereka terima. Pendapatan rendah yang diterima akan berakibat pula pada rendahnya tabungan. Sebagai konsekuensinya, rendahnya tabungan maka rendah pula investasinya.

Indonesia merupakan negara berkembang yang tingkat kemiskinannya masih tinggi. Jhingan (2000) mengemukakan ada tiga ciri utama negara berkembang yang menjadi penyebab dan sekaligus akibat yang saling terkait pada kemiskinan. Pertama, prasarana dan sarana pendidikan yang tidak memadai sehingga menyebabkan tingginya jumlah penduduk buta huruf dan tidak memiliki keterampilan ataupun keahlian. Kedua, sarana kesehatan dan pola konsumsi buruk sehingga hanya sebagian kecil penduduk yang bisa menjadi tenaga kerja produktif. Ketiga, penduduk terkonsentrasi di sektor pertanian dan pertambangan dengan metode produksi yang telah usang dan ketinggalan zaman.

Oleh karena itu, perlu suatu keberanian untuk memutus rantai penyebab kemiskinan. Salah satu caranya yaitu dengan memperbaiki kualitas sumber daya manusia yang berperan sebagai motor penggerak perekonomian suatu daerah (Wahyu, 2015).

Kualitas sumber daya manusia dapat dilihat dari indeks kualitas hidup/indeks pembangunan manusia. Rendahnya Indeks Pembangunan Manusia (IPM) akan berakibat pada rendahnya produktivitas kerja dari penduduk. Produktivitas yang rendah berakibat pada rendahnya perolehan pendapatan. Sebagai dampaknya, rendahnya pendapatan menyebabkan tingginya jumlah penduduk miskin.

Todaro (2000) menyatakan bahwa pembangunan manusia merupakan tujuan pembangunan itu sendiri.Yang mana pembangunan manusia memainkan peranan kunci dalam membentuk kemampuan sebuah negara dalam menyerap teknologi modern dan untuk mengembangkan kapasitasnya agar tercipta pertumbuhan serta pembangunan yang berkelanjutan.

Salah satu upaya meningkatkan kualitas sumber daya manusia adalah melalui pendidikan. Sebagai contoh adalah sistem pendidikan Kazakhstan, melewati proses transformasi, meningkatkan kualitas program pendidikan dan berusaha untuk sesuai dengan standar internasional untuk membentuk sumber daya manusia yang berkualitas (Abdiraymova et al., 2015) . Pendidikan merupakan bagian yang sangat penting dalam pembangunan karena pendidikan bisa dijadikan sebagai investasi jangka panjang untuk membangun dan mengembangkan manusia Indonesia seutuhnya. Analisis yang diusulkan menunjukkan bahwa investasi dalam modal manusia memiliki dampak yang signifikan terhadap pertumbuhan ekonomi dari setiap negara, sehingga dianggaplah modal manusia menjadi lebih penting daripada kekayaan alam yang dimiliki oleh suatu bangsa (Naemtu, 2015). Melalui pendidikan, diharapkan bangsa Indonesia menjadi bangsa yang cerdas, memiliki ilmu pengetahuan, teknologi, seni, serta iman dan takwa yang baik. 
Ketersediaan dan keterjangkauan pendidikan merupakan kunci peningkatan sumber daya manusia. Sarana pendidikan yang memadai dan terjangkau oleh semua lapisan masyarakat dan kualitas pendidik yang bermutu mutlak diperlukan untuk mengurangi kemiskinan.

Pemerintah Indonesia berupaya memberikan pendidikan yang layak, terjangkau, dan merata. Namun mengingat begitu banyak problem pendidikan di Indonesia di mana masing-masing daerah memiliki karakteristik sendiri, pemerintah tampaknya tidak dapat menyelenggarakan pendidikan secara sendiri. Perlu adanya campur tangan swasta di dalam menyelenggarakan pendidikan yang layak, terjangkau, dan merata.

Sektor swasta, dalam hal ini adalah perusahaan, dapat turut serta dalam program penyediaan pendidikan yang layak, terjangkau, dan merata. Perusahaan melalui program Community Development merupakan suatu elemen yang penting dalam kerangka sustainability yang mencakup aspek ekonomi, lingkungan, dan sosial budaya.

Alasan penting mengapa suatu perusahaan harus melakukan program Community Development adalah untuk mendapatkan keuntungan sosial, mencegah konflik dan persaingan yang terjadi, kesinambungan usaha/bisnis, pengelolaan sumber daya alam serta pemberdayaan masyarakat, dan sebagai License to Operate. Jadi, implementasi Community Development bagi perusahaan tidak hanya untuk mendapatkan keuntungan ekonomi semata, tetapi juga keuntungan secara sosial dan lingkungan di mana pada akhirnya turut memengaruhi keberlanjutan perusahaan serta mencegah terjadinya konflik (Budimanta, 2004).

Program Community Development pada akhirnya dapat dijadikan tolak ukur bagi pembangunan nasional yang bersifat kontekstual yang mengikuti pola-pola budaya dan juga kehidupan masyarakat Indonesia yang berbedabeda. Community Development memang memiliki beberapa tahapan yang pada dasarnya sesuai dengan kondisi masyarakat sekitar perusahaan, seperti adanya program pembangunan melalui pemberdayaan masyarakat.

Konsep Community Development dan CSR merupakan sesuatu yang berbeda. CSR adalah prinsip-prinsip atau konsep pengejawantahan dari pembangunan berkelanjutan, sedangkan Community Development adalah program pengejawantahan wujud CSR kepada eksternal yang ada di lingkungan perusahaan. Program Community Development ini mempunyai tiga tahapan program yaitu hubungan komunitas (community relation), pelayanan komunitas (community services), dan pada akhirnya mengarah pada pemberdayaan komunitas (community empowerment).

Salah satu perusahaan yang konsisten akan peningkatan sumber daya manusia dan peningkatan kualitas pendidikan adalah PT Badak NGL. Perusahaan yang bergerak di bidang pengolahan gas alam cair dan terletak di Kota Bontang, Kalimantan Timur ini, melalui program Community Development turut meningkatkan pendidikan guna peningkatan kualitas SDM dan pemecahan masalah kemiskinan. Hal ini selaras dengan kebijakan Kota Bontang yakni Pemerintah Kota Bontang yang telah menetapkan program pendidikan dasar 12 tahun, di mana warga Bontang wajib memiliki pendidikan minimal setara dengan SLTA. Program tersebut tidak hanya untuk menuntaskan pendidikan dasar, tetapi juga memiliki lulusan yang berkualitas, sebagaimana visi pendidikan yang telah ditetapkan, yaitu "Mewujudkan Pendidikan Tuntas Berkualitas, Menuju Masyarakat Cerdas, dan Berbudi Luhur".

Visi pendidikan yang dicetuskan Pemerintah Kota Bontang sangatlah indah yaitu pendidikan yang layak, terjangkau, dan merata. Namun, dalam pelaksanaannya untuk mewujudkan visi tersebut tidaklah mudah. Permasalahan dalam pembangunan pendidikan di Kota Bontang dipengaruhi oleh beberapa faktor, salah satunya adalah faktor geografis yaitu keadaan pemukiman penduduk yang terpencarpencar dan terpencil serta pemukiman yang 
padat. Faktor lain yang berpengaruh adalah mulai beragamnya suku, budaya, tingkat SDM, serta tingkat ekonomi masyarakat Bontang.

Oleh karena itu, PT Badak NGL melalui program Community Development melaksanakan program "BADAK PEDULI PENDIDIKAN" di mana dalam pelaksanaannya bersinergi dengan para stakeholder agar tepat sasaran. Bentuk program pendidikan yang dimaksud diarahkan langsung kepada masyarakat yang membutuhkan sebagai bentuk kepedulian perusahaan terhadap peningkatan SDM agar memiliki kualitas daya saing yang tinggi.

Untuk memberdayakan masyarakat diperlukan kebijakan, komitmen, organisasi, dan program serta pendekatan yang tepat. Lebih dari itu, diperlukan juga sikap yang bukan memberlakukan orang miskin sebagai objek, melainkan sebagai subjek. Orang miskin bukanlah orang yang tidak memiliki apapun, melainkan orang yang memiliki sesuatu walaupun hanya sedikit (Bayo Ala, 1981:31). Pemberdayaan adalah proses transformasi dengan upaya penggalian segenap potensi yang ada menjadi lebih bermanfaat. Maka, diperlukan sebuah strategi atau arah baru kebijaksanaan pembangunan yang memadukan pertumbuhan dan pemerataan pembangunan terutama masyarakat miskin.

Kartasasmita (1995:18) menyatakan bahwa memberdayakan masyarakat adalah upaya untuk meningkatkan harkat dan martabat lapisan masyarakat yang dalam kondisi sekarang tidak mampu melepaskan diri dari perangkap kemiskinan dan keterbelakangan. Dengan kata lain, memberdayakan masyarakat adalah memampukan dan memandirikan masyarakat. Upaya untuk mewujudkan hal tersebut dapat dilakukan dengan tiga langkah : (a) Menciptakan suasana atau iklim yang memungkinkan masyarakat untuk berkembang (enabling); (b) Memperkuat potensi alat daya yang dimiliki masyarakat (empowering); dan (c) Melindungi (protecting).

Berdasarkan latar belakang tersebut, tujuan dalam penelitian ini adalah (1) mengidentifikasi model implementasi program Community Development bidang pendidikan yang dilakukan PT Badak NGL dan (2) mengidentifikasi dampak implementasi program Community Development bidang pendidikan.

\section{METODE PENELITIAN}

Jenis data dalam penelitian ini dibedakan menjadi dua, yaitu : (1) data primer dan (2) data sekunder. Data primer diperoleh dalam bentuk verbal atau kata-kata dan perilaku subjek (informan) yang berkaitan dengan penelitian. Adapun data sekunder bersumber dari dokumendokumen program Community Development bidang pendidikan (laporan seleksi penerima beasiswa, prestasi penerima beasiswa), foto-foto, rekaman, dan benda-benda yang digunakan sebagai pelengkap data primer.

Dalam pengambilan data primer, penentuan informan didasarkan pada kriteria berikut : (1) subjek menyatu dengan medan aktivitas sasaran penelitian; (2) subjek masih aktif; (3) subjek memiliki waktu untuk dimintai informasi; dan (4) subjek tidak memiliki hubungan spesial dengan peneliti.

Sehubungan dengan kriteria tersebut dan disesuaikan dengan tujuan penelitian maka pemilihan informan dilakukan dengan teknik purposive sampling. Teknik ini digunakan dengan tujuan mengarahkan pengumpulan data agar sesuai dengan kebutuhan dan dilakukan dengan menyeleksi informan yang benar-benar menguasai materi serta permasalahan yang ada dan dapat dipercaya. Penggunaan teknik purposive memberikan kebebasan peneliti dari keterikatan proses formal yang berarti peneliti dapat menentukan sampling sesuai dengan tujuan penelitian berdasarkan substansi permasalahan. Sampling yang dimaksud adalah bukan sampling yang mewakili populasi melainkan didasarkan pada relevansi dan kedalaman informasi yang didapat.

Adapun informan yang dijadikan sampel dalam penelitian ini yaitu pegawai dari Dinas Pendidikan Kota Bontang, kepala SMA Vidatra, 
peserta magang Cooperative Education Program (COOP) PT Badak NGL, penerima beasiswa (SMP, SMA, dan LNG Academy), dan orang tua penerima beasiswa. Agar diperoleh data secara holistik dan integratif serta memperhatikan relevansi data dengan fokus penelitian, rumusan masalah, dan tujuan maka pengumpulan data menggunakan teknik: (1) wawancara mendalam; (2) observasi; (3) kuesioner; dan (4) studi dokumentasi. Teknik wawancara yang digunakan adalah wawancara tidak terstruktur (unstructured interview) yaitu dilakukan tanpa menyusun suatu daftar pertanyaan yang ketat. Melalui wawancara tidak terstruktur peneliti mencatat respon-respon afektif yang nampak selama proses wawancara berlangsung, dan kemudian memilah-milah serta mengamati kultur, budaya, dan cara hidup mereka. Adapun isu pokok yang digali melalui wawancara antara lain mekanisme pelaksanaan CSR bidang pendidikan yang dilakukan oleh PT Badak NGL, aktor yang terlibat, serta kendala-kendala internal maupun eksternal. Teknik observasi digunakan sebagai pelengkap dan dilakukan melalui dua tahap yaitu: (1) dimulai dengan observasi deskriptif secara luas dengan melukiskan sarana dan prasarana yang ada; dan (2) observasi terfokus untuk melihat proses pelaksanaan program Community Development bidang pendidikan.

Teknik analisis dalam penelitian ini adalah dengan menggunakan metode deskriptif kualitatif yaitu metode dengan cara mengelompokkan data, memilah-milah data, dan memberikan gambaran umum penjelasan pada data sesuai dengan teori seperti yang ada di landasan teori untuk kemudian ditarik suatu kesimpulan. Pada pendekatan kualitatif, data dianalisa dengan menggunakan model interaktif yaitu melalui proses pengumpulan data dan penyajian data. Pada saat data yang disajikan belum dapat disimpulkan atau ditemukan kejanggalan-kejanggalan maka data direduksi melalui verifikasi. Reduksi data dilakukan terusmenerus selama pengumpulan data berlangsung. Sejak analisis data dan verifikasi dilakukan, maka pada saat itu juga peneliti mulai memberi arti dan memaknai data yang diperoleh. Keputusan peneliti memberi arti tersebut pada dasarnya adalah untuk menarik kesimpulan sementara yang masih memungkinkan untuk diperbaiki. Kesimpulan sementara yang belum jelas direduksi kembali melalui verifikasi. Kemudian setelah peneliti yakin bahwa kesimpulan telah kuat, maka peneliti memaknai hasil penelitian dengan menginterpretasikan makna-makna tersebut dalam bentuk simpulan akhir.

\section{HASIL DAN PEMBAHASAN}

Kota Bontang terletak antara $117^{\circ} 26^{\prime} 34,86^{\prime \prime}$ Bujur Timur sampai $0^{\circ} 4^{\prime} 7,34^{\prime \prime}$ Lintang Utara. Wilayah Kota Bontang didominasi oleh lautan. Kota Bontang memiliki wilayah daratan seluas $149,8 \mathrm{~km} 2(30,10 \%)$ dan luas wilayah lautan $347,77 \mathrm{~km}^{2} \quad(69,9 \%)$, sedangkan luas wilayah seluruhnya adalah $497,57 \mathrm{~km}^{2}$ (BPS, 2015).

Secara administrasi, semula Kota Bontang merupakan kota administrasi sebagai bagian dari Kabupaten Kutai dan menjadi daerah otonom berdasarkan Undang-undang No. 47 Tahun 1999 tentang pemekaran Propinsi dan Kabupaten, bersama-sama dengan Kabupaten Kutai Timur, Kutai Barat, dan Kabupaten Kutai Kartanegara. Sejak disahkannya Peraturan Pemerintah Daerah Kota Bontang No. 17 tahun 2002 tentang Pembentukan Organisasi Kecamatan Bontang Barat, pada tanggal 16 Agustus 2002 Kota Bontang terbagi menjadi 3 kecamatan yaitu Bontang Selatan $\left(104,40 \mathrm{~km}^{2}\right)$, Bontang Utara $\left(26,20 \mathrm{~km}^{2}\right)$, dan Bontang Barat $\left(19,20 \mathrm{~km}^{2}\right)$. Pembangunan pendidikan di Kota Bontang dipengaruhi oleh beberapa faktor. Salah satunya adalah faktor geografis di mana keadaan pemukiman penduduk terpencar-pencar dan terpencil serta pemukiman yang padat. Faktor lain yang berpengaruh adalah mulai beragamnya suku, budaya, serta tingkat SDM dan tingkat ekonomi masyarakat Bontang. Kebijakan pemerintah terhadap dunia pendidikan sangat baik, di mana pemerintah Kota Bontang telah menetapkan program pendidikan dasar 12 tahun. 
Warga Bontang wajib memiliki pendidikan minimal setara dengan SLTA. Program tersebut tidak hanya untuk menuntaskan pendidikan dasar, tetapi juga memiliki lulusan yang berkualitas, sebagaimana visi pendidikan yang telah ditetapkan yaitu "Mewujudkan Pendidikan Tuntas Berkualitas, Menuju Masyarakat Cerdas dan Berbudi Luhur".Salah satu perusahaan terbesar yang ada di Kalimantan Timur tepatnya di Kota Bontang adalah PT Badak NGL yang merupakan produsen Liquefied Natural Gas (LNG) dan Liquefied Petroleum Gas (LPG). PT Badak NGL merupakan perusahaan nirlaba yang seluruh asetnya dimiliki oleh Pemerintah Republik Indonesia di bawah Kementerian Keuangan. Sejak awal berdirinya, PT Badak NGL berkomitmen dalam pemenuhan program Community Development dan memberikan peluang bagi perusahaan untuk ikut andil dalam pengembangan masyarakat. Salah satunya, dengan melakukan program Community Development di bidang pendidikan. PT Badak NGL melalui program Community Development "BADAK PEDULI PENDIDIKAN" dilaksanakan bersinergi dengan para stakeholder agar menjadi tepat sasaran. Bentuk program pendidikan yang dimaksud diarahkan langsung kepada masyarakat yang membutuhkan sebagai bentuk kepedulian perusahaan terhadap peningkatan SDM agar memiliki kualitas daya saing yang tinggi.

\section{Implementasi Program Community Development Bidang Pendidikan}

Dengan berbagai macam masalah pendidikan yang ada, PT Badak NGL melalui Community Development Bidang Pendidikan membuat berbagai program yang sesuai dengan kondisi yang ada di Kota Bontang.

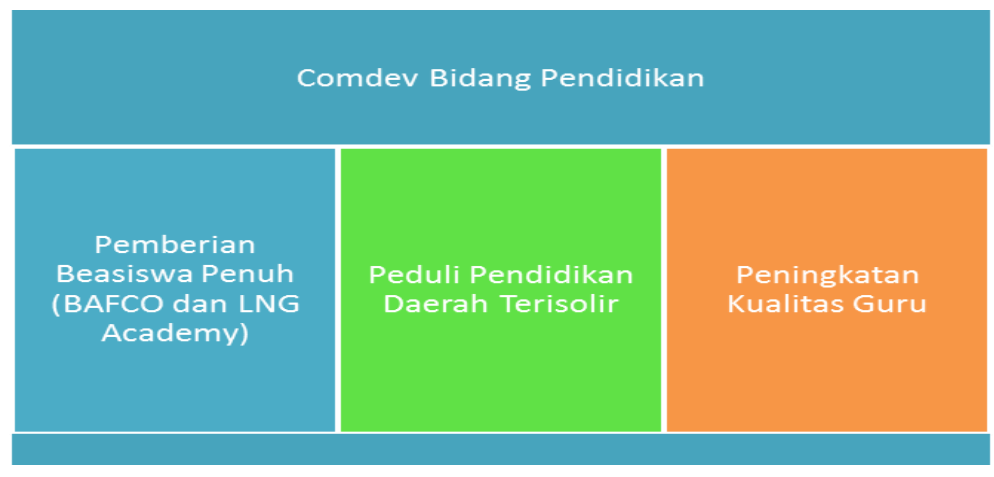

Gambar 1. Program Community Development Bidang Pendidikan yang dilakukan oleh PT Badak NGL.

Sumber : Laporan Program Community Development PT Badak NGL

Pada gambar 1, terlihat bahwa program Community Development bidang pendidikan yang diberikan PT Badak NGL ada 3 jenis yaitu pemberian beasiswa, fasilitasi siswa sekolah terisolir untuk mengikuti UN, dan peningkatan kualitas guru. Adapun implementasi program program tersebut akan dijelaskan sebagai berikut:

Pemberian Beasiswa Penuh (BAFCO \& LNG Academy), Sebagai upaya untuk mendorong peningkatan jumlah dan kualitas pendidikan 12 tahun, PT Badak NGL telah melakukan Program Beasiswa Full Scholarship (BAFCO / Badak Full Scholarship) dengan subprogram penjaringan penerimaan beasiswa SMP, SMA, dan Perguruan Tinggi. BAFCO merupakan program beasiswa penuh diberikan kepada siswa/siswi lulusan SD, SMP, dan SMA khusus bagi warga Bontang di mana biaya belajar ditanggung oleh PT Badak NGL. Program ini diperuntukkan bagi siswa-siswi yang berprestasi dibidang akademik, tetapi memiliki latar belakang ekonomi keluarga yang kurang mampu. 


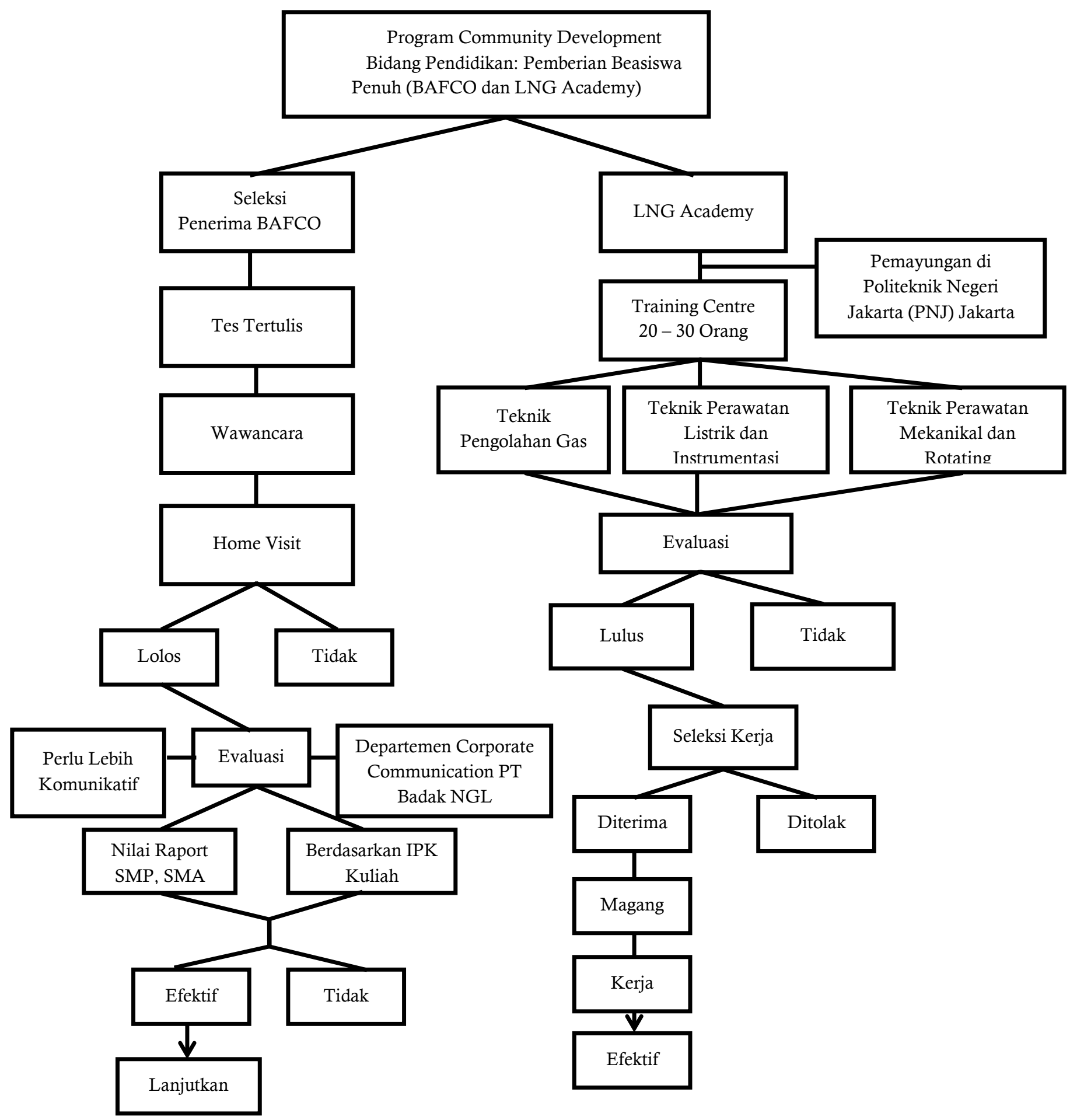

Gambar 2. Model Implementasi Pemberian Beasiswa Penuh dari PT Badak NGL Sumber : data primer, diolah 
Adapun model implementasi pemberian beasiswa BAFCO (gambar 2) yang telah dilakukan adalah sebagai berikut: PT Badak NGL melakukan publikasi mengenai penerimaan beasiswa BAFCO melalui media cetak, elektronik, maupun sosial. Calon penerima BAFCO mengumpulkan berkas persyaratan di Departemen Corporate Communication PT Badak NGL selaku perwakilan perusahaan dalam proses seleksi penerima BAFCO ini. Departemen tersebut selanjutnya melakukan proses seleksi untuk menentukan para peserta yang akan mengikuti tes tertulis. Perusahaan menunjuk SMP Vidatra dan SMA Vidatra sebagai penyelenggara tes tertulis dan membuat peringkat hasil tes tertulis untuk dilaporkan kembali kepada Departemen Corporate Communication PT Badak NGL. Empat puluh orang yang menduduki peringkat 40 besar berdasarkan tes tertulis tersebut akan dipanggil oleh PT Badak NGL untuk mengikuti wawancara. Tahap ini dilakukan untuk melengkapi informasi dari berkas yang dikumpulkan serta melihat kematangan siswa calon penerima BAFCO. Dari proses wawancara ini, peserta akan disaring menjadi 20 orang siswa calon penerima BAFCO. Setelah wawancara, pihak PT Badak NGL melakukan survey lapangan (home visit) ke rumah orang tua 20 siswa calon penerima BAFCO. Home visit ini dilakukan tanpa pemberitahuan sebelumnya. Hal ini dilakukan untuk mendapatkan informasi yang sebenarnya atas kondisi sosial ekonomi siswa calon penerima BAFCO. Setelah informasi lengkap, Departemen Corporate Communication PT Badak NGL akan melakukan pembobotan atas keseluruhan rangkaian seleksi calon siswa penerima BAFCO. Adapun pembobotan penilaiannya dapat dilihat pada Gambar 3.

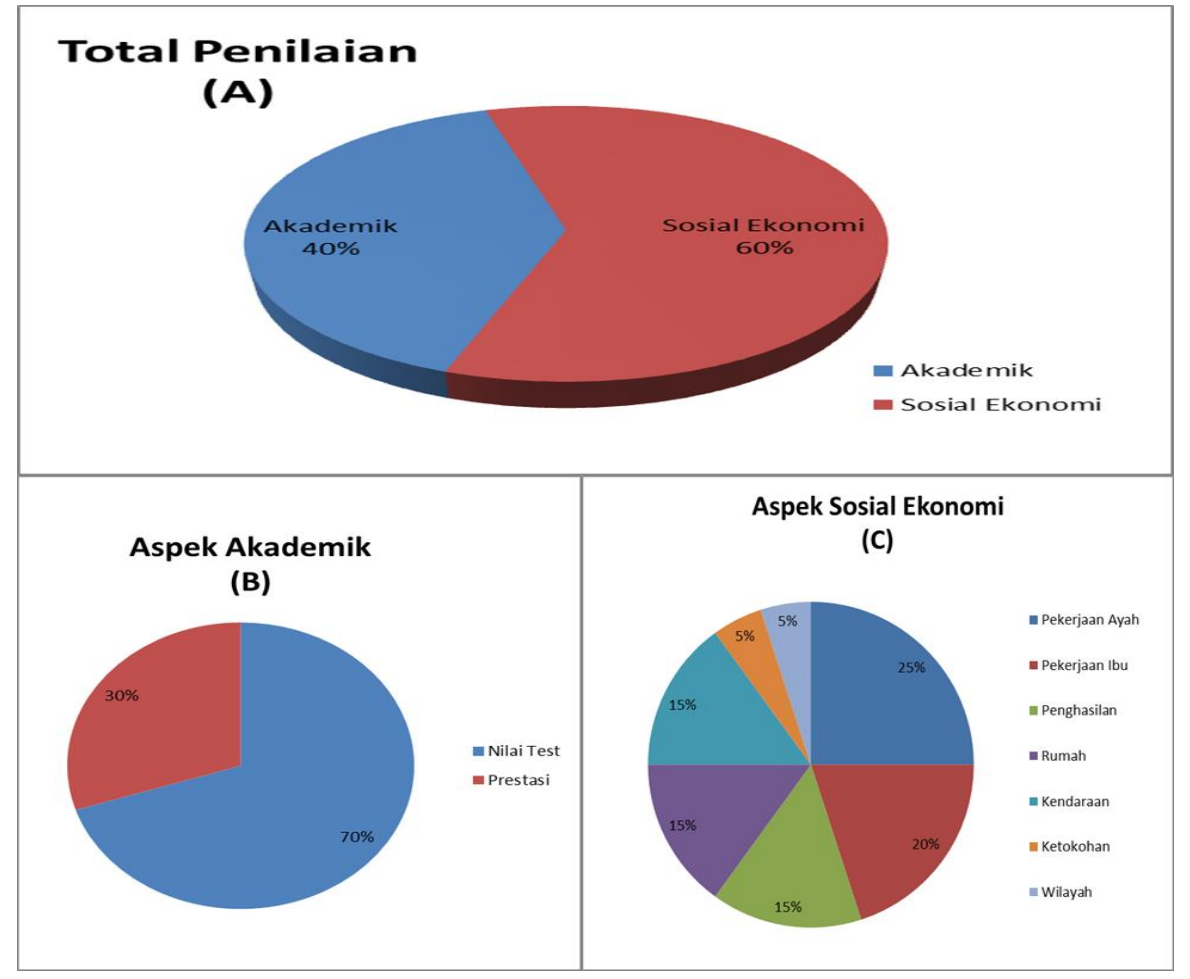

Gambar 3. Kriteria Penilaian Seleksi Penerima Bafco

Sumber: data sekunder, 2015

Berdasarkan gambar 3A, calon penerima beasiswa BAFCO berasal dari keluarga yang sosial ekonominya kurang mampu dan siswa tersebut berprestasi. Penilaian akademik 
memiliki bobot $40 \%$ dan kondisi sosial ekonomi memiliki bobot $60 \%$. Di dalam penilaian akademik yang bobot totalnya $40 \%$, masih dibreak down lagi aspek penilaiannya yaitu nilai tes siswa sebesar $70 \%$ berdasarkan penilaian test akademik yang dibuat peringkatnya oleh pihak sekolah SMP dan SMA Vidatra serta prestasi yang berhasil diraih selama 3 tahun terakhir sebesar 30\% (gambar 3B). Adapun aspek penilaian sosial ekonomi meliputi penilaian terhadap pekerjaan ayah, pekerjaaan ibu, penghasilan yang didapat orang tua, kondisi rumah, kendaraan yang dimiliki, ketokohan dari orang tua, dan wilayah tempat tinggal siswa (gambar 3C).

Jika seluruh penilaian telah selesai dilakukan, PT Badak NGL mengumumkan daftar penerima beasiswa BAFCO. Penerima beasiswa BAFCO lulusan SD atau SMP akan melanjutkan pendidikannya di SMP Vidatra atau SMA Vidatra serta mendapatkan fasilitas pendidikan meliputi biaya pendidikan, seragam, buku pelajaran, kegiatan ekstra kulikuler, uang transportasi, serta biaya siswa mengikuti kegiatan sekolah ke luar daerah (transportasi, akomodasi, dan biaya lainnya).

Tabel 1. Penerima BAFCO SMP dan BAFCO SMA PT Badak NGL

\begin{tabular}{llll}
\hline \multicolumn{1}{c}{ Keterangan } & \multicolumn{1}{c}{$\begin{array}{c}\text { BAFCO } \\
\text { SMP }\end{array}$} & $\begin{array}{c}\text { BAFCO } \\
\text { SMA }\end{array}$ \\
\hline $\begin{array}{l}\text { Tahun mulai } \\
\text { program }\end{array}$ & 2000 & 2000 \\
$\begin{array}{l}\text { Penerima } \\
\text { (orang) }\end{array}$ & 188 & 205 \\
$\begin{array}{l}\text { Lulus (orang) } \\
\text { Masih aktif }\end{array}$ & 153 & 173 \\
belajar (orang) & 35 & 42 \\
\hline
\end{tabular}

Sumber: data sekunder, 2015

Berdasarkan Tabel 1 dapat diketahui bahwa Program BAFCO SMP dan SMA dimulai tahun 2000. Jumlah siswa yang menerima BAFCO mulai dari tahun 2000 - 2015 untuk kategori siswa SMP adalah 188 orang, di mana
153 orang telah lulus SMP dan 35 orang masih duduk di bangku sekolah. Sedangkan pada kategori SMA, ada 205 orang penerima BAFCO dan yang sudah lulus sebanyak 173 orang serta sisanya sebanyak 42 orang masih aktif belajar di SMA.

Pihak sekolah SMP Vidatra dan SMA Vidatra adalah jembatan penghubung komunikasi antara siswa penerima BAFCO dengan Departemen Corporate Communication PT Badak NGL. Informasi terkait pencairan beasiswa BAFCO, pengajuan pembiayan untuk mengikuti kegiatan perlombaan, pelaporan hasil belajar siswa (raport), serta prestasi kejuaraan yang diraih siswa disampaikan kepada pihak sekolah yang akan meneruskan informasi tersebut kepada PT Badak NGL. Dalam hal ini, penerima BAFCO tidak langsung berkomunikasi dengan pihak Perusahaan karena segala sesuatunya dikomunikasikan via sekolah. Oleh karena itu, penerima BAFCO tidak mengetahui siapa nama-nama pihak PT Badak NGL yang selama ini telah membantu mereka dalam pemenuhan kebutuhan belajarnya. Alangkah baiknya, jika ke depannya ada suatu forum yang mempertemukan antara penerima BAFCO dengan PT Badak NGL untuk mempermudah komunikasi di antara keduanya.

Selain tingkat SMP dan SMA, program BAFCO juga diberikan kepada siswa yang akan memasuki jenjang perguruan tinggi. Proses seleksi bagi penerima BAFCO Perguruan Tinggi tidak jauh berbeda dengan program BAFCO untuk SMP dan SMA. Program beasiswa ini merupakan beasiswa penuh bagi lulusan peserta BAFCO tingkat SMA yang diseleksi berdasarkan kemampuan akademis dari kelas X-XII. Jumlah peserta program BAFCO adalah 10 anak di setiap angkatan. Siswa dapat memilih semua jurusan yang dikendaki, tetapi terbatas pada perguruan tinggi yang telah ditunjuk oleh PT Badak NGL. Fasilitas yang diperoleh adalah bimbingan belajar persiapan masuk perguruan tinggi, biaya pendidikan, laptop, tas kuliah, biaya makan, alat tulis, KKN, dan biaya wisuda. 
Program BAFCO Perguruan Tinggi dimulai tahun 2013 dengan penerima yang tersebar di berbagai perguruan tinggi, yaitu Universitas Gadjah Mada sebanyak 14 orang, Universitas Diponegoro ada 1 orang, Institut Teknologi Sepuluh November Surabaya ada 1 orang, Institut Teknologi Bandung ada 1 orang, Universitas Brawijaya Malang sebanyak 6 orang, dan Universitas Airlangga Surabaya 1 orang (PT Badak NGL, 2015).

Ada aturan khusus untuk penerima BAFCO Perguruan Tinggi yaitu mereka harus melaporkan IPK tiap semester kepada pihak PT Badak NGL. Minimal IPK yang didapat untuk program studi kategori eksak adalah 3,3 dan untuk program studi non eksak adalah 3,5. Jika IPK yang didapat mahasiswa penerima BAFCO melebihi ketentuan tersebut, ia berhak mendapatkan reward berupa transportasi pulang pergi dari universitas tempat mereka studi ke Bontang. Sebaliknya, bila IPK mahasiswa penerima BAFCO lebih rendah dari ketentuan tersebut, ia akan menerima konsekuensi berupa pemotongan uang living cost sebesar $\mathrm{Rp}$ 300.000,00 (tiga ratus ribu rupiah) hingga IPKnya mampu mencapai batas minimum yang dipersyaratkan.

Aturan lain bagi mahasiswa penerima BAFCO adalah pembatasan masa studi. Mahasiswa BAFCO yang mengambil jurusan kedokteran harus menyelesaikan masa studinya maksimal 10 semester dan mahasiswa BAFCO non kedokteran batas studinya adalah 8 semester.

Setelah mahasiswa penerima BAFCO lulus Strata 1 (S1) dan telah bekerja, mereka memiliki kewajiban untuk mengembalikan biaya yang telah diterimanya selama kuliah sebesar $70 \%$ kepada PT Badak NGL. Kebijakan ini diambil untuk memberikan kesempatan yang sama bagi adik kelasnya (lulusan SMA) yang ingin melanjutkan kuliah di perguruan tinggi dan menumbuhkan rasa tanggung jawab serta kesetiakawanan sosial lulusan S1 penerima BAFCO kepada adik kelasnya. Program ini diharapkan dapat memandirikan para penerima BAFCO.
Merujuk pada teori lingkaran setan kemiskinan (vicious cycle of poverty), kebijakan pengembalian biaya kuliah yang diterapkan mahasiswa penerima BAFCO juga diharapkan dapat memutus lingkaran kemiskinan. Teori itu sendiri berbicara mengenai penyebab kemiskinan yang tidak tahu asal muasalnya dan akan terus berputar, tidak berujung pangkal, dan penanggulangannya perlu dengan memutus rantai penyebab kemiskinan tersebut. Dengan pendidikan yang memadai, produktivitas akan meningkat dan diiringi pendapatan yang juga meningkat sehingga menyebabkan tingginya tabungan dan mengurangi angka kemiskinan.

Pemberian beasiswa penuh dari PT Badak NGL tidak hanya melalui program BAFCO, tetapi juga melalui LNG Academy. LNG Academy merupakan program pendidikan kerja sama antara PT Badak NGL dengan Politeknik Negeri Jakarta dengan jenjang pendidikan Diploma III (D-3). Dimulai sejak tahun akademik 2011 - 2012, program ini berada pada Jurusan Teknik Mesin - Program Studi Teknik Konversi Energi - Konsentrasi Teknik Pengolahan Gas dan memiliki 3 (tiga) konsentrasi yaitu: (a) Teknik Pengolahan Gas / Gas Processing ; (b) Teknik Perawatan Mekanikal dan Rotating / Mechanical Rotary; dan (c) Teknik Perawatan Listrik dan Instrumentasi / Electrical Maintance. Ketiga jenis konsentrasi yang ditawarkan tersebut mengacu pada kebutuhan operasional utama kilang gas alam cair (Sunaryo, dkk: 2015).

LNG Academy menerima 20-30 orang peserta didik setiap angkatannya dengan kuota calon mahasiswa yang diterima dari Kalimatan Timur sekitar 30\%. Namun, persentase tersebut tidak bersifat pasti dan wajib karena tetap mengacu pada hasil tes yang dilakukan.

Fasilitas yang didapat penerima beasiswa LNG Academy yaitu bebas biaya perkuliahan dan living cost, berkesempatan magang di PT Badak NGL, dan jika berminat dapat bekerja di PT Badak NGL setelah menyelesaikan studi serta lulus tes seleksi kerja. 
Tabel 2. Proses Input hingga Impact BAFCO SMP, SMA, Perguruan Tinggi, dan LNG Academy

\begin{tabular}{|c|c|c|c|c|}
\hline Keterangan & BAFCO SMP & BAFCO SMA & $\begin{array}{l}\text { BAFCO } \\
\text { Perguruan } \\
\text { Tinggi }\end{array}$ & LNG Academy \\
\hline Input & $\begin{array}{lr}\text { Sumber } & \text { daya } \\
\text { fisik dan finansial }\end{array}$ & $\begin{array}{l}\text { Sumber daya fisik } \\
\text { dan finansial }\end{array}$ & $\begin{array}{lr}\text { Sumber } & \text { daya } \\
\text { fisik } & \text { dan } \\
\text { finansial } & \end{array}$ & $\begin{array}{l}\text { Sumber daya fisik } \\
\text { dan finansial }\end{array}$ \\
\hline Output & $\begin{array}{l}\text { Kesempatan } \\
\text { belajar }\end{array}$ & $\begin{array}{l}\text { Kesempatan } \\
\text { belajar }\end{array}$ & $\begin{array}{l}\text { Kesempatan } \\
\text { belajar }\end{array}$ & $\begin{array}{l}\text { Mendapat beasiswa, } \\
\text { fasilitas dan } \\
\text { kesempatan bekerja }\end{array}$ \\
\hline Outcome & Lulus SMP & Lulus SMA & Sarjana (S1) & $\begin{array}{l}\text { Mendapat } \\
\text { pengalaman kerja } \\
\text { dan ijazah Diploma }\end{array}$ \\
\hline Impact & $\begin{array}{l}\text { Memiliki daya } \\
\text { saing yang } \\
\text { berkualitas untuk } \\
\text { masuk ke jejaring } \\
\text { SMA favorit }\end{array}$ & $\begin{array}{lr}\text { Memiliki } & \text { daya } \\
\text { saing } & \text { yang } \\
\text { berkualitas } & \text { untuk } \\
\text { masuk } & \text { ke } \\
\text { universitas } & \text { favorit }\end{array}$ & $\begin{array}{l}\text { Memutus rantai } \\
\text { kemiskinan, } \\
\text { Pembangunan } \\
\text { kota }\end{array}$ & $\begin{array}{lr}\text { Peningkatan SDM } \\
\text { tingkat mahasiswa } \\
\text { yang } \\
\text { dalam pompeten } \\
\text { LNG }\end{array}$ \\
\hline
\end{tabular}

Sumber : data sekunder, diolah

\section{Peduli Pendidikan Daerah Terisolir}

Perbedaan geografis, perbedaan sumber daya alam dan kualitas sumber daya manusia, serta perbedaaan peranan sektor swasta dan negara adalah beberapa faktor penyebab kemiskinan yang dikemukakan oleh Todaro (1997). Mengacu pada teori dari Todaro serta melihat kondisi pemukiman penduduk Kota Bontang yang sebagian letaknya terpencar, berada di daerah terpencil, serta terletak di kawasan padat, PT Badak NGL di dalam program Community Development bidang pendidikan turut peduli pada pendidikan daerah terisolir.

Bekerja sama dengan Dinas Pendidikan Kota Bontang, PT Badak NGL melakukan layanan 3T yaitu pembinaan pendidikan di daerah terdepan, terpencil, dan tertinggal. Komitmen peduli pendidikan daerah terisolir diwujudkan dengan memberi bantuan fasilitas berupa boarding community di lingkungan Perusahaan bagi anak-anak sekolah yang akan mengikuti Ujian Nasional dari daerah terisolir untuk dapat melakukan Ujian Nasional di pusat Kota Bontang. Ada tujuh sampai delapan sekolah tempat siswa-siswa daerah terisolir yang difasilitasi oleh PT Badak NGL. Selama masa persiapan Ujian Nasional tersebut, PT Badak NGL juga menyediakan akomodasi, konsumsi, dan pendampingan selama siswa daerah terisolir tersebut berada di lingkungan PT Badak NGL untuk mengikuti Ujian Nasional.

Melalui program Badak Peduli Pendidikan Daerah Terisolir, PT Badak NGL telah berperan serta dalam meningkatkan kesempatan jumlah anak dari daerah terisolir untuk menyelesaikan tingkat pendidikannya. Peningkatan kesempatan akan berimbas pada peningkatan mutu sumber daya manusia Kota Bontang dan pada akhirnya dapat mengurangi tingkat kemiskinan yang terjadi di Kota Bontang.

\section{Peningkatan Kualitas Guru}

Program Community Development PT Badak NGL yang juga bekerja sama denga Dinas Pendidikan Kota Bontang adalah Peningkatan Kualitas Guru. Melalui program ini, PT Badak NGL memberi fasilitas untuk pembinaan peningkatan kualitas guru di daerah pesisir melalui pelatihan guru. Pelatihan guru 
yang diberikan terbagi dalam 3 termin yakni teori, praktik mengajar di kelas, dan praktik di kelas dipantau, disesuaikan dengan kondisi yang ada.

Dengan mengadakan pelatihan, kualitas guru yang ada di Kota Bontang dapat meningkat. Tahap selanjutnya, guru dapat meningkatkan mutu mengajar kepada para anak didik sehingga pada akhirnya kualitas sumber daya di Kota Bontang pun meningkat dan berdampak pula untuk mengurangi tingkat kemiskinan.

\section{Dampak Program Community Development Bidang Pendidikan PT Badak NGL}

Adanya program-program Community Development yang dilakukan oleh PT Badak NGL di bidang pendidikan menimbulkan dampak positif bagi masyarakat Kota Bontang baik secara khusus maupun secara umum. Dampak secara khusus dari program ini dipaparkan sebagai berikut.

Pertama, peningkatan jumlah anak yang bersekolah dari keluarga yang kurang mampu. Cita-cita anak dari keluarga yang kurang mampu secara sosial ekonomi yaitu ingin mengenyam pendidikan setinggi-tingginya dapat terwujud. Pada mulanya, anak tersebut kecil hati dan patah arang karena anak tersebut tidak akan dapat mewujudkan cita-citanya. Kemampuan akademiknya memang mencukupi, tetapi kemampuan finansial dari orang tuanya tidaklah mencukupi sehingga anak tersebut tidak dapat mewujudkan mimpinya.

Adanya program beasiswa penuh khususnya BAFCO yang diberikan PT Badak NGL memberi harapan baru bagi anak-anak yang berprestasi dari keluarga yang kurang mampu secara sosial ekonomi untuk dapat mewujudkan mimpinya. Dengan BAFCO, mereka mendapatkan akses pendidikan yang cukup sehingga bisa membantu mewujudkan cita-citanya.

Kedua, peningkatan jumlah anak yang bersekolah dari daerah terisolir. Kondisi geografis Kota Bontang yang kurang memadai untuk akses pendidikan adalah salah satu penyebab tidak meratanya pendidikan di Kota Bontang. Melihat keadaan tersebut, PT Badak NGL memfasilitasi anak-anak sekolah dari daerah terpencil dengan memberi bantuan akomodasi dan transportasi untuk tinggal sementara di lingkungan PT Badak NGL guna melaksanakan Ujian Akhir Nasional. Anak-anak daerah terpencil dapat lulus sehingga mereka siap untuk melanjutkan pendidikan yang lebih tinggi dan memperbaiki taraf hidup mereka.

Ketiga, peningkatan kualitas pendidikan. Adanya program peningkatan kualitas guru dengan memberikan pelatihan-pelatihan diharapkan mampu meningkatkan pula kualitas dan kompetensi para guru dalam proses belajarmengajar.

Keempat, menciptakan lulusan yang kompeten dalam bidang migas khususnya pengolahan LNG serta memiliki kualitas daya saing yang tinggi. Dengan beasiswa untuk lulusan SMA melalui program LNG Academy, secara tidak langsung pemerintah terbantu dalam mengurangi angka pengangguran. Hal ini terjadi karena LNG Academy mencetak lulusan yang berkompeten dan handal di bidang migas. Kurikulum LNG Academy disusun sesuai kebutuhan pasar tenaga kerja khususnya kebutuhan pekerja di bidang migas. Lulusan LNG Academy pun dapat bersaing di kancah global. 


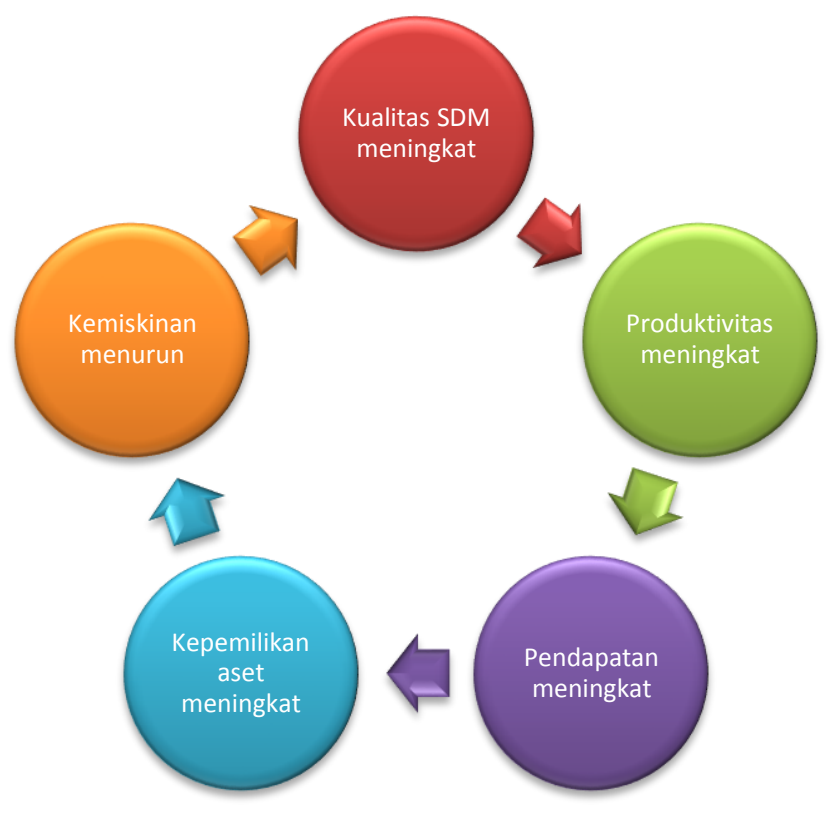

Gambar 4. Dampak Implementasi Program Community Development bidang Pendidikan PT Badak NGL

Sumber: data primer, diolah

Selain dampak khusus tersebut, dampak secara umum dari program Community Development bidang pendidikan PT Badak NGL yaitu mengurangi kemiskinan. Hal ini dapat terlihat dari Gambar 4 di atas dengan penjelasan sebagai berikut: Pertama, siswa dari keluarga tidak mampu dapat mengenyam pendidikan hingga level Perguruan Tinggi. Ini berarti keberadaan bantuan beasiswa membuat siswa mampu mendapatkan akses pendidikan sehingga meningkatkan kualitas sumber daya manusianya. Semakin tinggi jenjang pendidikan yang diraih, semakin meningkat pula produktivitasnya. Mereka dapat mengisi jenis-jenis pekerjaan yang membutuhkan keahlian khusus. Sebagai imbalannya, mereka akan mendapatkan pendapatan yang tinggi pula. Dengan pendapatan yang tinggi, kepemilikan aset dapat meningkat sehingga akhirnya berdampak pada mengurangi kemiskinan.

Oleh karena itu, inti dari program Community Development bidang pendidikan yang dilakukan oleh PT Badak NGL adalah memandirikan masyarakat melalui program- program yang mendorong peningkatan kualitas dan kuantitas pendidikan. Pada akhirnya, tujuan dari program ini untuk mengurangi kemiskinan dapat terwujud.

\section{SIMPULAN}

Salah satu upaya mengurangi tingkat kemiskinan di Indonesia adalah peningkatan kualitas pendidikan. Penyelenggaraan pendidikan yang bermutu memerlukan kerja sama triple helix antara pemerintah, perusahaan, dan masyarakat.

Dari sektor perusahaan, upaya yang dapat dilakukan di antaranya melalui program Community Development bidang pendidikan. PT Badak NGL adalah salah perusahaan yang peduli dengan peningkatan mutu pendidikan. Perusahaan ini pun mengadakan program Community Development di bidang pendidikan meliputi Pemberian Bantuan Beasiswa Penuh Melalui Program BAFCO dan LNG Academy dengan serangkaian proses seleksi; Badak Peduli Pendidikan Daerah Terisolir dengan memberi 
fasilitas anak-anak dari daerah terisolir untuk mengikuti Ujian Nasional di pusat Kota Bontang; dan Peningkatan Kualitas Guru melalui serangkaian pelatihan kepada guru sebagai upaya peningkatan kualitas sumber daya manusia.

Adanya program-program Community Development yang dilakukan oleh PT Badak NGL di bidang pendidikan menimbulkan dampak positif bagi masyarakat Kota Bontang baik secara khusus maupun secara umum. Secara khusus, program ini dapat meningkatkan kualitas pendidikan dan sumber daya manusia di Kota Bontang. Adapun secara umum, program ini membantu menurunkan tingkat kemiskinan di Kota Bontang.

\section{DAFTAR PUSTAKA}

Abdiraymova, G.S. et al., 2015. Higher Education In Kazakhstan: New Opportunities And The Problem Of Crystallization Of Middle Strata Status. Procedia-Social and Behavioral Sciences, 177, pp.142-146.

Alfitri. 2011. Community Development: Teori dan Aplikasi. Yogyakarta : Pustaka Pelajar.

Arsyad, Lincolin. 1997. Ekonomi Pembangunan. Yogyakarta: STIE YKPN.

Bayo Ala, Andre.1981. Kemiskinan dan Strategi Memerangi Kemiskinan. Yogyakarta: Liberty.

Budimanta Arif, Rudito Bambang, Prestyo Adi 2004. Corporate Social Responsibility: Jawaban Bagi Model Pembangunan Indonesia Masa Kini. Jakarta: Penerbit ICSD.

BPS Kota Bontang. 2015. Bontang dalam Angka Tahun 2015. Bontang.

Fitriyani, Intan. 2011. Analisis Efektivitas Program Kemitraan PT Bank X dengan Usaha Kecil di Bogor. Skripsi. Institut Pertanian Bogor.

Hanke, T and W. Stark. 2009. Strategy Development : Conceptual Framework On Corporate Social Responsibility. Journal of Business Ethics 85 : 507516.

Hidayat, Syarif dan Darwin Syamsulbahri. 2007. Pemberdayaan Ekonomi Rakyat Sebuah Rekonstruksi Konsep Community Based Development (CBD). Jakarta: PT Pustaka Quantum.

Jhingan. 2000. Ekonomi Pembangunan dan Perencanaan. Jakarta: Rajawali Press.
Kartasasmita, Ginanjar. 1995. "Pemberdayaan Masyarakat: Sebuah Tinjauan Adminisrtrasi", Pidato Pengukuhan Jabatan Guru Besar Dalam Ilmu Administrasi Pada Fakultas Ilmu Administrasi Universitas Brawijaya, Malang, 27 Mei 1995.

Kuncoro, Mudrajad. (2006) Ekonomika Pembangunan : Teori, Masalah dan Kebijakan. Yogyakarta: UPP STIM YKPN.

Moelong, Lexi J .2007. Metodologi Penelitian Kualitatif ( Resived Ed ) .Bandung: Remaja Rosdakarya.

Naemtu, D.M., 2015. Education, The Economic Development Pillar. Procedia-Social and Behavioral Sciences, 180, pp.413-420.

PT. Badak NGL. 2015. Laporan Program Community Development PT. Badak NGL. Bontang : PT Badak NGL.

PT. Badak NGL. 2015. Grand Design Bafco PT. Badak NGL : SMP, SMA dan Perguruan Tinggi. Bontang : PT Badak NGL.

PT. Badak NGL. 2015. Term of Reference Community Development Program Pendidikan PT Badak. Bontang : PT Badak NGL.

Saputro, Nurantono Setyo. 2010. Dampak Kegiatan Corporate Sosial Responsibility (CSR) PT. Telkom terhadap Kemampuan Masyarakat dalam Mengakses Sumber Daya di Kawasan Punclut Bandung. Jurnal Perencanaan Wilayah dan Kota, Vol. 21 No. 2, Agustus 2010, hlm. 129 -146 .

Sumodiningrat, Gunawan. 1997. Pembangunan Daerah dan Pemberdayaan Masyarakat. Jakarta: PT Bina Rena Pariwara.

Sunaryo, Busori, dkk. 2015. Dampak LNG Academy terhadap Kesiapan Tenaga Kerja Baru di Badak LNG. Jurnal Ekonomi dan Kebijakan Vol. 8 No. 1 Maret 2015: 1 - 9 .

Sunaryo, Busori., \& Agus M. Irkham. 2015. PendarPendar Kepedulian: Kisah Pencapaian Badak LNG Meraih Proper Emas. Jakarta: Badak LNG.

Todaro, Michael P. 2000. Pembangunan Ekonomi di Dunia Ketiga. Jakarta: Erlangga.

Turker, D. 2008. How Corporate Social Responsibility Influences Organizational Commitment. Journal of Business Ethics 89:189-204.

Wahyu, Dita. 2015. Analisis Determinan Kemiskinan di Provinsi Jawa Tengah Tahun 2008 Sampai 
Eddy Cahyadi dan Reta Yudistyana / Economics Development Analysis Journal 5 (2) (2016)

2012. Jurnal Ekonomi dan Kebijakan Vol. 8 no. 1 Maret 2015.

Widodo, Tri. 2006. Perencanaan Pembangunan: Aplikasi Komputer (Era Otonomi Daerah). Yogyakarta: UPP STIM YKPN

Qi, D. \& Wu, Y., 2015. A Multidimensional Child Poverty Index in China. Children and Youth Services Review, 57, pp.159-170. 